\title{
Carbohydrate intake for optimal performance in professional male \& female tennis players
}

\author{
Lorena Martin (USA)
}

ITF Coaching and Sport Science Review 2015; 66 (23): 18 - 21

\begin{abstract}
Many coaches and athletes underestimate the competitive advantage that proper carbohydrate intake can have on athletic performance. The intake and timing of carbohydrates may be the differentiating factor between victory and defeat. Remember there are many variables in the equation of optimal performance. In this article we will review some fundamentals on carbohydrate intake for optimal performance both in professional male and female tennis players.
\end{abstract}

\author{
Key words: nutrition, nutrients, \\ training \\ Received: 21 March 2015 \\ Accepted: 18 Juy 2015 \\ Corresponding author: \\ Lorena Martin \\ Email: \\ lorena.martin@northwestern.edu
}

\section{INTRODUCTION}

Under the umbrella of sports nutrition, there are factors such as nutrient timing, sex, age, injuries, number of hours training, body composition, etc., that play a contributing role to the performance of professional tennis players (Burke et al, 1989; Burke et al, 1993; Costill et al, 1988; Coyle, 1991). One of the most important nutrients that can affect all the previously mentioned variables is carbohydrate intake.

It has been well documented in the literature that carbohydrate intake affects both physiological and psychological performance (Krieder et al, 1995; Ostojic, 2002). How so? Well, this article aims to explain the mechanisms of how carbohydrates can help with training load, match endurance, and post-match recovery and how they differ between male and female professional tennis players.

Importance of carbohydrates for performance

In the most recent position statement of the International Olympic Committee (IOC) on nutrition for athletes, it was stated: "A high carbohydrate diet in the days before competition will help enhance performance, particularly when exercise lasts longer than about $60 \mathrm{~min}$ and athletes should aim to achieve carbohydrate intakes that meet the fuel requirements of their training programs and also adequately replace their carbohydrate stores during recovery between training sessions and competition" (Jeukendrup, 2004). Other research studies have shown that ingesting carbohydrates during prolonged exercise results in a reversal of fatigue (Coggan et al, 1991; Coyle, 1995; Coyle et al, 1983).

In addition, other studies have shown performance improvement is likely to be related to maintenance of high rates of carbohydrate oxidation and the prevention of hypoglycemia (Ivy, 1991; Ivy et al, 2003; Ivy et al, 2004). An analysis of all studies available shows that a carbohydrate ingested during exercise will be oxidised at rates up to about 1 $\mathrm{g} / \mathrm{min}$, even when large amounts of carbohydrates have been previously ingested (Jeukendrup, 2004; Wagenmakers et al, 1993). With this in mind, if you measure and weigh your tennis player's food prior to consumption you can estimate how much carbohydrates they are using while training and how much remains post-training.

This improved performance after a high carbohydrate diet was linked with the higher muscle glycogen concentrations observed after such a diet (Wee et al, 2005). A high carbohydrate diet (70\% of dietary energy from carbs) and elevated muscle glycogen stores seemed to enhance endurance capacity compared to a normal (50\% carbs) and a low (10\% carbs) carbohydrate diet (Jeukendrup, 2004; Simonsen et al, 1991). As competitive coaches and players we know that endurance is a major factor in the third set in most tennis matches and definitely a protagonist in men's five set matches.

There is current controversy on the efficacy of liquid vs. solid form of carbohydrates. According to research, it does not seem to affect the ergogenic potential (DiMeglio et al, 2000; Mason et al, 1993; Pan et al, 2011). Hargreaves studied the effects of ingestion of a candy bar $43 \mathrm{~g}$ of $\mathrm{CHO}, 9 \mathrm{~g}$ of fat, and $3 \mathrm{~g}$ of protein)and observed a $46 \%$ improvement in sprint capacity after $4 \mathrm{~h}$ of exercise compared with placebo ingestion. Others studies confirmed that liquid and solid carbohydrates improved exercise performance to a similar degree (Burke et al, 1998; Hargreaves, 1991).

\section{Carbohydrates and exercise physiology}

It is well known that carbohydrates are the form of energy that muscles prefer (Mason et al, 1993). As a matter of fact, they are stored in muscles and liver in the form of glycogen (Colye, 1995). It is important that you are aware that your brain also loves carbs, as it survives on glucose (preferably carbs that are broken down to glucose molecules). In fact, the brain uses more glucose than any other organ or tissue in the body at rest (Lienhard et al, 1992; Sokoloff, 1973). However, the brain can alternatively function with an alternate fuel, Ketone bodies (glucose derived from the breakdown of protein and fats), but this is not its preference. This occurs when you deprive your body of carbohydrates for an extended period of time, causing your body to breakdown fats and proteins, resulting in ketone bodies (Lienhard et al, 1992; Sokoloff, 1973).

Carbohydrates breakdown into smaller sugars that ultimately get absorbed and utilised in order to provide you with energy (Askew, 1975; Frery et al, 1983). Any glucose that is not used right away gets stored in the muscles and the liver in the form of glycogen (Cummings et al, 1986). Glycogen is the source of energy most often used while you are training on the tennis court (Peters, 1941). Glycogen stores are needed for short, intense bouts of exercise from sprinting to weight lifting because it is immediately accessible, thus making it essential for the anaerobic sprints during a tennis match. Glycogen also supplies energy during the first few minutes of any sport (Maughan et al, 1981; Maughan, 2002; Gastin, 2001; Cardwell, 
2012; Muth, 2014; Manore et al, 2014; McArdle et al, 2010). During long, slow duration exercise, fat can help fuel activity, but glycogen is still needed to help breakdown the fat into something the muscles can use. However, once these glycogen stores are filled up, any additional carbohydrates get stored as fat, hence why most people avoid eating carbohydrates.

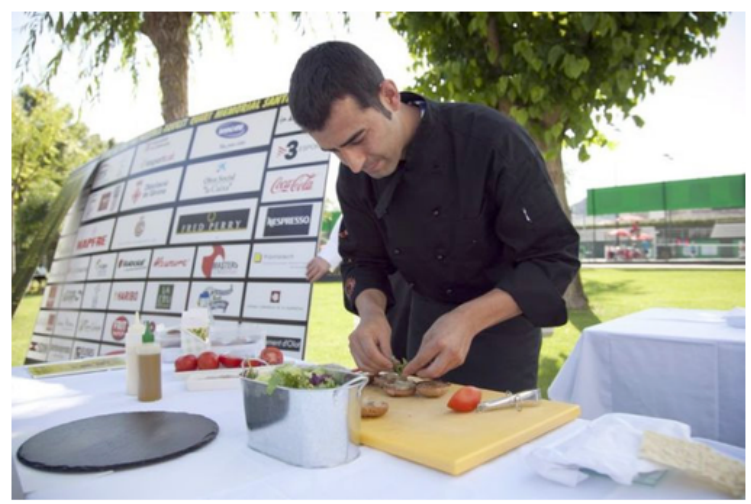

Below is a table delineating the physiological processes that occur based on intensity and duration of training. This table provides a better picture of the importance of carbohydrate intake in the sport of tennis.

\begin{tabular}{|c|c|c|c|c|c|}
\hline FACTORS & $\begin{array}{c}\text { ATP } \\
\text { SYSTEM }\end{array}$ & $\begin{array}{c}\text { PCR - } \\
\text { CREATINE } \\
\text { PHOSPHATE }\end{array}$ & $\begin{array}{l}\text { ANAEROBIC } \\
\text { GLYCOLYSIS }\end{array}$ & $\begin{array}{l}\text { AEROBIC } \\
\text { GLYCOLYSIS }\end{array}$ & $\begin{array}{l}\text { FATTY ACID } \\
\text { OXIDATION }\end{array}$ \\
\hline $\begin{array}{l}\text { Amount } \\
\text { stored for } \\
\text { energy } \\
\text { utilisation }\end{array}$ & $\begin{array}{c}5 \\
\text { mmoles } \\
/ \mathrm{kg}\end{array}$ & $\begin{array}{c}17 \text { mmoles/ } \\
\mathrm{kg}\end{array}$ & $\begin{array}{c}350 g \\
\text { glycogen } \\
\text { stored in } \\
\text { muscle }\end{array}$ & $\begin{array}{l}440 g \\
\text { glycogen } \\
\text { stored } \\
\text { muscle/liver }\end{array}$ & $\begin{array}{l}9,000- \\
15,000 \mathrm{~g}\end{array}$ \\
\hline $\begin{array}{l}\text { Duration of } \\
\text { training }\end{array}$ & $\begin{array}{c}0.3 \\
\text { seconds }\end{array}$ & $\begin{array}{c}4-10 \\
\text { seconds }\end{array}$ & $\begin{array}{c}120 \\
\text { seconds - } 4 \\
\text { mins }\end{array}$ & $1-2$ hours & $\begin{array}{l}\text { Over } 2 \\
\text { hours }\end{array}$ \\
\hline $\begin{array}{l}\text { Physiological } \\
\text { limitation }\end{array}$ & $\begin{array}{l}\text { Utilized } \\
\text { at the } \\
\text { start of } \\
\text { sprints }\end{array}$ & $\begin{array}{l}\text { Utilized } \\
\text { in short } \\
\text { sprints }\end{array}$ & $\begin{array}{l}\text { Limited by } \\
\text { hydrogen } \\
\text { ion } \\
\text { formation }\end{array}$ & $\begin{array}{l}\text { Limited by } \\
\text { oxygen and } \\
\text { pyruvate } \\
\text { transport to } \\
\text { mitochondria } \\
\text { for energy } \\
\text { release }\end{array}$ & $\begin{array}{c}\text { Slow, it } \\
\text { takes a } \\
\text { while to } \\
\text { dip into } \\
\text { these } \\
\text { stores as } \\
\text { FFA release } \\
\text { is much } \\
\text { more } \\
\text { complex }\end{array}$ \\
\hline
\end{tabular}

Table 1. The table above denotes the energy utilisation systems in five discrete categories, however, many other texts combine them into three major systems.

Carbohydrate intake for professional tennis players

The appropriate carbohydrate intake depends on whether you are training, competing, or recovering. Tennis players should be consuming carbohydrates before, during, and post competition. In general, research has concluded that elite athletes require 3.1 to 4.5 grams of carbohydrate per day per pound of body weight, while non- athletes need only 1.8 to 2.3 grams per pound per day (Maughan, 2002; Gastin, 2001). It is also recommended to eat a good source of carbohydrate (sweet potato vs. French fries) anywhere from 1 to 4 hours before exercise helps keep plenty of blood glucose available for working muscles (Cardwell, 2012; Muth, 2014; Manore et al, 2014; McArdle et al, 2010).

To find out how many grams of carbohydrates you need, first determine how many hours you train, and then multiply the recommended grams of carbohydrate by your body weight to determine your daily carbohydrate requirement. For example, after running some analyses on body weight on the top 50 professional male tennis players during 2012, the mean weight was 179 lbs. Thus, you would multiply by 5 grams (if they are training at least three hours a day) and that would give you their estimated recommended intake of $895 \mathrm{~g}$ of Carbohydrate intake for that particular day (training load of three hours). Remember this means that calorie wise this athlete should be consuming 3,580 calories of carbohydrates (this is not their total daily caloric intake). Usually, carbohydrates are recommended to be $45-70 \%$ (this is only for athletes, usual recommendations are between $45-55 \%$ ) of an athlete's diet. Thus, if we assume this was only $50 \%$ of their total caloric intake, this male professional tennis player should be ingesting a total of 7,160 calories for that day!

Below is a quick reference table to give you an idea of the recommended grams of carbohydrates based on training load. It is suggested that females would tend toward the lesser values, while the males aim to consume towards the upper values listed below (not necessarily because of sex, but because of height and weight).

Carbohydrate intake based on training load

Here is a quick reference to calculating nutrient needs!

\begin{tabular}{|c|c|}
\hline TRAINING LEVEL & $\begin{array}{c}\text { GRAMS OF CARBOHYDRATE PER } \\
\text { POUND PER DAY }\end{array}$ \\
\hline 1 hour per day & 2.7 to 3.1 grams \\
\hline 2 hours per day & 3.6 grams \\
\hline 3 hours per day & 5 grams \\
\hline
\end{tabular}

Table 2. Guide to calculating nutrient needs.

Differences in Weight, BMI, and Carbohydrate Needs between the Top 50 Male and Female Professional Tennis Players In addition, to discussing the basics of carbohydrates, I examined a small sample of the top 50 ATP tour male professional tennis players and top 50 WTA tour female professional tennis players from the year 2012. A simple descriptive analysis using $\mathrm{R}$ was run in order to obtain mean and ranges for weight and BMI of both the top 50 ATP and WTA tour players for the year 2012. Results are shown on table 3.

\begin{tabular}{|c|c|c|c|c|}
\hline $\begin{array}{c}2012 \text { TOP } 50 \\
\text { PROS }\end{array}$ & $\begin{array}{c}\text { WEIGHT } \\
\text { MEAN }\end{array}$ & \multicolumn{1}{c}{$\begin{array}{c}\text { WEIGHT } \\
\text { RANGE }\end{array}$} & BMI MEAN & BMI RANGE \\
\hline Females & 141.1 & $121-165$ & 21 & $16.99-24.12$ \\
\hline Males & 179.3 & $150-245$ & 23.03 & $20.62-26.25$ \\
\hline
\end{tabular}

Table 3. Mean values and ranges for weight and BMI for the 2012 top 50 ATP and WTA tour players.

So as you can see, the needs for a female professional tennis player are much different than the carbohydrate needs for a male professional tennis player. Let's suppose you wanted to compare what the minimum amount of carbohydrate intake for a top 50 female professional tennis player compared to the maximum according to the two previous tables. A female weighing in at $121 \mathrm{lbs}$. (121lbs $\times 5 \mathrm{~g}$ if training 3 hours) would need $605 \mathrm{~g}$ of carbohydrates vs. a female tennis pro weighing in at $165 \mathrm{lbs}$. (165lbs $\times 5 \mathrm{~g}$ if training 3 hours), which would need $825 \mathrm{~g}$ of carbohydrates.

Now let's take a look at the carbohydrate needs of top 50 male professional tennis players. A male weighing at $150 \mathrm{lbs}$ (150 lbs. $x 5 \mathrm{~g}$ if training 3 hours $)=750 \mathrm{~g}$ of carbohydrates vs. a male weighing in at $245 \mathrm{lbs}$. ( $245 \times 5 \mathrm{~g}$ if training 3 hours $)=1,225 \mathrm{~g}$ of carbohydrates. In summary, this is a simple way to help your elite athletes get the proper carbohydrate intake to meet their carbohydrate needs on and off the court.

\section{CONCLUSION}


Finally, it is important to understand that carbohydrates can aid in your training, during match performance and also in your recovery. Remember that the key is to know when to take them, which to take, and how much to intake. As with any optimal training plan, breaking down your carbohydrate intake to a science for personalisation can give you the competitive edge you need to win.

\section{REFERENCES}

Askew, E. W., Dohm, G. L., \& Huston, R. L. (1975). Fatty acid and ketone body metabolism in the rat: Response to diet and exercise. The Journal of Nutrition, 105(11), 14221432.https://doi.org/10.1093/jn/105.11.1422

Burke, L. M., \& Read, R. S. (1989). Sports nutrition. Sports Medicine, 8(2), 80100.https://doi.org/10.2165/00007256198908020-00002

Burke, L. M., Collier, G. R., \& Hargreaves, M. (1993). Muscle glycogen storage after prolonged exercise: Effect of the glycemic index of carbohydrate feedings. Journal of Applied Physiology (Bethesda, Md.: 1985), 75(2), 10191023.https://doi.org/10.1152/jappl.1993.75.2.101 9

Burke, L. M., Collier, G. R., \& Hargreaves, M. (1998). Glycemic index-A new tool in sport nutrition? International Journal of Sport Nutrition, 8, 401415.https://doi.org/10.1123/ijsn.8.4.401

Cardwell, G. (2012). Gold medal nutrition Human kinetics.https://doi.org/10.5040/9781492595557

Costill, D. L., Flynn, M. G., Kirwan, J. P., Houmard, J. A., Mitchell, J. B., Thomas, R., \& Park, S. H. (1988). Effects of repeated days of intensified training on muscle glycogen and swimming performance. Med Sci Sports Exerc, 20(3), 249254.https://doi.org/10.1249/00005768198806000-00006

Coyle, E. F. (1991). Timing and method of increased carbohydrate intake to cope with heavy training, competition and recovery. Journal of Sports Sciences, 9(S1), 2952.https://doi.org/10.1080/02640419108729865

Coggan, A. R., \& Coyle, E. F. (1991). 1 carbohydrate ingestion during prolonged exercise: Effects on metabolism and performance. Exercise and Sport Sciences Reviews, 19(1), 140.https://doi.org/10.1249/00003677199101000-00001

Coyle, E. F. (1995). Substrate utilization during exercise in active people. The American Journal of Clinical Nutrition, 61(4 Suppl), 968S979S.https://doi.org/10.1093/ajcn/61.4.968S

Coyle, E. F., Hagberg, J. M., Hurley, B. F., Martin, W. H., Ehsani, A. A., \& Holloszy, J. O. (1983). Carbohydrate feeding during prolonged strenuous exercise can delay fatigue. Journal of Applied Physiology: Respiratory, Environmental and Exercise Physiology, 55(1 Pt 1), 230235.https://doi.org/10.1152/jappl.1983.55.1.230

Currell, K., \& Jeukendrup, A. (2008). Superior endurance performance with ingestion of multiple transportable carbohydrates. Medicine Science in Sports Exercise, 40(2), 275.https://doi.org/10.1249/mss.0b013e31815adf 19
Cummings, J. H., Englyst, H. N., \& Wiggins, H. S. (1986). The role of carbohydrates in lower gut function. Nutrition Reviews, 44(2), 5054.https://doi.org/10.1111/j.17534887.1986.tb07586.x

DiMeglio, D. P., \& Mattes, R. D. (2000). Liquid versus solid carbohydrate: Effects on food intake and body weight. International Journal of Obesity, 24(6), 794800.https://doi.org/10.1038/sj.ijo.0801229

Fery, F., \& Balasse, E. O. (1983). Ketone body turnover during and after exercise in overnight-fasted and starved humans. The American Journal of Physiology, 245(4), E31825.https://doi.org/10.1152/ajpendo.1983.245.4.E3 18

Gastin, P. B. (2001). Energy system interaction and relative contribution during maximal exercise. Sports Medicine, 31(10), 725-

741.https://doi.org/10.2165/00007256 200131100-00003

Hargreaves, M. (1991). Carbohydrates and exercise. Journal of Sports Sciences, 9(S1), 1728.https://doi.org/10.1080/02640419108729864

Ivy, J. L. (1991). Muscle glycogen synthesis before and after exercise. Sports Medicine, 11(1), 619.https://doi.org/10.2165/00007256199111010-00002

Ivy, J. L., Res, P., Sprague, R., \& Widzer, M. (2003). Effect of a carbohydrate-protein supplement on endurance performance during exercise of varying intensity. International Journal of Sport Nutrition and Exercise Metabolism, 13, 382395.https://doi.org/10.1123/ijsnem.13.3.382

Ivy, J., \& Portman, R. (2004). Nutrient timing: The future of sports nutrition Basic Health Publications, Inc.

Jeukendrup, A. E. (2004). Carbohydrate intake during exercise and performance. Nutrition, 20(7), 669677.https://doi.org/10.1016/j.nut.2004.04.017

Kreider, R. B., Hill, D., Horton, G., Downes, M., Smith, S., \& Anders, B. (1995). Effects of carbohydrate supplementation during intense training on dietary patterns, psychological status, and performance. International Journal of Sport Nutrition, 5, 125125.https://doi.org/10.1123/ijsn.5.2.125

Lienhard, G. E., Slot, J. W., James, D. E., \& Mueckler, M. M. (1992). How cells absorb glucose. Sci Am, 266(1), $86-$ 91.https://doi.org/10.1038/scientificamerican0192 $-86$

Manore, M., Meyer, N. L., \& Thompson, J. (2009). Sport nutrition for health and performance Human Kinetics.

Maughan, R., \& Poole, D. (1981). The effects of a glycogenloading regimen on the capacity to perform anaerobic exercise. European Journal of Applied Physiology and Occupational Physiology, 46(3), 211-219.https://doi.org/10.1007/BF00423397

Maughan, R. (2002). The athlete's diet: Nutritional goals and dietary strategies. Proceedings of the Nutrition Society, 61(01), 8796.https://doi.org/10.1079/PNS2001132

Mason, W. L., McConell, G., \& Hargreaves, M. (1993). Carbohydrate ingestion during exercise: Liquid vs solid feedings. Medicine and Science in Sports and Exercise, 25(8), 966969.https://doi.org/10.1249/00005768199308000-00013 
McArdle, W. D., Katch, F. I., \& Katch, V. L. (2010). Exercise physiology: Nutrition, energy, and human performance Lippincott Williams \& Wilkins.

Muth, N. D. (2014). Sport nutrition for health professionals FA Davis

Ostojic, S. M., \& Mazic, S. (2002). Effects of a carbohydrateelectrolyte drink on specific soccer tests and performance. Journal of Sports Science \& Medicine, 1(2), 47.

Pan, A., \& Hu, F. B. (2011). Effects of carbohydrates on satiety: Differences between liquid and solid food. Current Opinion in Clinical Nutrition and Metabolic Care, 14(4), 385-390. doi:10.1097/MCO.0b013e328346df36 [doi]https://doi.org/10.1097/MCO.0b013e328346 df36

Peters, J. P. (1941). A new frame for metabolism. The Yale Journal of Biology and Medicine, 13(6), 739-758.

Simonsen, J. C., Sherman, W. M., Lamb, D. R., Dernbach, A. R., Doyle, J. A., \& Strauss, R. (1991). Dietary carbohydrate, muscle glycogen, and power output during rowing training. Journal of Applied Physiology (Bethesda, Md.: 1985), 70(4), 15001505.https://doi.org/10.1152/jappl.1991.70.4.150 0

Sokoloff, L. (1973). Metabolism of ketone bodies by the brain. Annual Review of Medicine, 24(1), 271280.https://doi.org/10.1146/annurev.me.24.02017 3.001415

Wagenmakers, A. J., Brouns, F., Saris, W. H., \& Halliday, D. (1993). Oxidation rates of orally ingested carbohydrates during prolonged exercise in men. Journal of Applied Physiology (Bethesda, Md.: 1985), 75(6), 2774

2780.https://doi.org/10.1152/jappl.1993.75.6.277 4

Wee, S. L., Williams, C., Tsintzas, K., \& Boobis, L. (2005). Ingestion of a high-glycemic index meal increases muscle glycogen storage at rest but augments its utilization during subsequent exercise. Journal of Applied Physiology (Bethesda, Md.: 1985), 99(2), 707- 714. doi:01261.2004

[pii]https://doi.org/10.1152/japplphysiol.01261.20 04

RECOMMENDED ITF TENNIS ACADEMY CONTENT (CLICK BELOW)

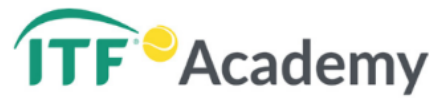

Copyright (c) Lorena Martin 2015

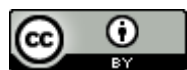

This text is under a Creative Commons BY 4.0

license

You are free to Share - copy and redistribute the material in any medium or format - and Adapt the content - remix, transform, and build upon the material for any purpose, even commercially under the following terms:

Attribution: You must give appropriate credit, provide a link to the license, and indicate if changes were made. You may do so in any reasonable manner, but not in any way that suggests the licensor endorses you or your use.

CC BY 4.0 license terms summary CC BY 4.0 license terms 